\title{
Effectiveness of Non-Performing Loans Management at the Penglatan Traditional Village Credit Institution (LPD)
}

\section{Ketut Suardika ${ }^{*}$, Mertyani Sari Dewi²}

1,2 Sekolah Tinggi Ilmu Ekonomi Satya Dharma, Singaraja, Indonesia

\section{ART I CLE I N F O}

\section{Article history:}

Received August 19, 2021

Revised August 20, 2021

Accepted October 20, 2021

Available online November 25, 2021

Keywords:

NPL, CAR, LDR, KAP, BOPO

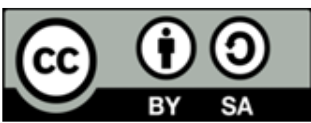

This is an open access article under the CC BY-SA license.

Copyright $(2021$ by Author. Published by Universitas Pendidikan Ganesha.

\begin{abstract}
A B S T R A C T
As a microfinance institution, the LPD, which is finance belonging to the village of Pakraman, aims to collect funds from the community to be further channeled back to the community. Seeing the critical role of the LPD as a micro institution in Bali, the LPD institution with traditional villages, and the government's desire to develop LPD in Bali, the existence of the LPD needs to be maintained and maintained. This study aims to determine the effectiveness of managing Non-Performing Loans (NPL) in LPd Desa Adat Penglatan through the Non-Performing Loan Ratio (NPL), Capital Adequacy Ratio (CAR), Loan to Deposit Ratio (LDR), Earning Asset Quality (KAP) and Costs. Operating Operating Income (BOPO). This research was conducted at the Village Credit Institution (LPD) of the Penglatan Traditional Village. The instrument used to collect data is a questionnaire. This study used a population and 36 months or three-year samples using the purposive sampling technique. The collection technique uses an observation process on financial statement data. The techniques used in analyzing the data are Multiple Linear Regression Analysis, Classical Assumption Test Analysis, FTest Analysis (F-Test), Determination Analysis, and T-Test Analysis (TTest). The results of this study explain that the Capital Adequacy Ratio (CAR) has a significant negative effect on Non-Performing Loans (NPL) and Loan to Deposit Ratio (LDR), Earning Assets Quality (KAP), and Operating Income Operating Costs (BOPO) have a significant influence for Non-Performing Loans (NPL).
\end{abstract}

\section{INTRODUCTION}

The development of a fast-growing economy in the era of globalization and the government's efforts to expand the active participation of the public in the business world in the form of development, has caused the role of the private sector engaged in services and trade to grow so rapidly that it can absorb labor and reduce unemployment (Gazzola et al., 2020; Hyman et al., 2021; Ibn-Mohammed et al., 2021). The Village Credit Institution (LPD) is one of the policies of the Bali Regional Government in an effort to channel capital assistance to rural communities in Bali to improve the village economy. The main activity of the LPD is to collect public funds in the form of savings and deposits, and channel them back to people in need and in the form of loans or credit (Adiputra \& Sujana, 2021; Suputra \& Hendrayanti, 2021). LPD is a name for a savings and loan business owned by traditional village communities located in the Province of Bali and is a means of rural people's economy (Jayanthi et al., 2021; Sanjaya et al., 2019). From the explanation above, it can be concluded that LPD is a company owned by traditional villages that has activities to collect public funds and distribute them back to those who need capital to improve the rural economy.

The LPD's largest income comes from lending, and every credit given cannot be separated from various risks that can threaten the health of the LPD (Adiputra \& Sujana, 2021; Saerang et al., 2014). NonPerforming Loan (NPL) is a measure of credit risk which is a parameter of the LPD's soundness level. LPDs are considered to have potential difficulties that endanger their business continuity if the ratio of nonperforming loans (Non Performing Loans) on a net basis is more than $5 \%$ of total loans. If it exceeds $5 \%$, it will affect the assessment of the LPD's health level. The higher the NPL level, the bank is unprofessional in managing its credit, as well as indicating that the risk level of lending to the bank is quite high in line with the high NPL (Konstantakis et al., 2016; Saerang et al., 2014). By knowing the NPL ratio of an LPD, the community and LPD managers can take wise steps in addressing and dealing with these problems. The increase or decrease in the NPL ratio in the LPD can be influenced by various factors, both internal and 
external to the PD. Quantitatively, the factors that affect NPL can be in the form of Capital Adequacy Ratio (CAR), Loan to Deposit Ratio (LDR), quality of productive assets (KAP), operational costs to operating income (BOPO). In addition, there are also other factors that cause non-performing loans, such as: poor credit analysis processes, failed products offered to customers, loans based on balance sheet strength rather than cash flow loans, banks too prioritize security, information asymmetry that leads to moral hazard, economic environment and political influence (Chikoko et al., 2012; Hapsari, 2012). Macroeconomically, the main cause of the high level of NPL is the economic slowdown, which can be seen from the statistically significant and large economic coefficient on GDP, unemployment and inflation rates (Skarica, 2014).

As a microfinance institution, LPD, which in fact is a financial institution belonging to the Pakraman village, basically aims to collect funds from the community to be further channeled back to the community, especially the Pakraman village community, which is often referred to as krama desa (Prena \& Kustina, 2017; Wilatini \& Wirakusuma, 2019). Village communities (karma desa) can obtain loans from the LPD with a certain amount even without collateral such as certificates, BPKB or the like on condition that they are guaranteed by the customary village. This means that the guarantee and supervision carried out by traditional villages on customer loyalty in LPDs is a very dominant factor in the development of LPDs as microfinance institutions in Bali. The same is true of the LPD's contribution to traditional villages. In accordance with the profit sharing above, $20 \%$ of the profit allocated for the development of the Traditional Village as the owner of the LPD is used to finance the interests of the traditional village such as repairing temples (places of worship), religious ceremonies, religious activities, and culture (Damayanthi, 2011; Sanjaya et al., 2019; Suwintana et al., 2018). Seeing the importance of the role of LPD as a micro institution in Bali, the attachment of LPD institutions to traditional villages and the government's desire to develop LPDs in Bali, the existence of LPDs seems to need to be maintained and maintained. This is what underlies the Bali provincial government, which is supported by the Regency City Government in Bali, has a strong desire to continue to develop, foster, and provide opportunities for the growth of new LPDs in every traditional village. The desire and commitment of the government above can also be seen from the realization made in providing initial capital for LPDs which is supported by formal regulations in the form of policies that strengthen the existence of LPDs by the Regional Government of the Province of Bali.

What is the government's desire and commitment to the development and existence of the LPD as mentioned above does not seem easy to achieve in the current era of intense competition (Andreana \& Wirajaya, 2018; Suarta \& Sudiadnyani, 2014). In the era of modernization and globalization that has penetrated all aspects of life, it is characterized by an effective, efficient and professional way of working and supported by sophisticated equipment. LPD is currently faced with financial institutions that work professionally and can provide services more quickly, accurately and efficiently. The ease of service that tends to pamper and "deify" consumers is one of the concrete manifestations of the tough competition that is currently being carried out by LPDs. By looking at competitors as above, LPD must be willing and able to change themselves to be more professional, effective and efficient so that they can bind consumers while maintaining their level of loyalty (Mahaendrayasa \& Putri, 2017; Prena \& Kustina, 2017). The LPD's largest income comes from lending, and every loan granted cannot be separated from various risks that can threaten the health of the LPD. LPDs are considered to have potential difficulties that endanger their business continuity if the ratio of non-performing loans (Non Performing Loans) on a net basis is more than $5 \%$ of total loans. If it exceeds 5\%, it will affect the assessment of the LPD's health level. The higher the NPL level, the bank is unprofessional in managing its credit, as well as indicating that the risk level of lending to the bank is quite high in line with the high NPL (Konstantakis et al., 2016; Saerang et al., 2014).

By knowing the NPL ratio of an LPD, the community and LPD managers can take wise steps in addressing and dealing with these problems. The increase or decrease in the NPL ratio in an LPD can be influenced by various factors, both internal and external to the LPD (Malik et al., 2022; Tomar \& Sharma, 2021). Quantitatively, the factors that affect NPL can be in the form of Capital Adequacy Ratio (CAR), Loan to Deposit Ratio (LDR), quality of productive assets (KAP), operational costs to operating income (BOPO). In addition, there are also other factors that cause non-performing loans, such as: poor credit analysis processes, failed products offered to customers, loans based on balance sheet strength rather than cash flow loans, banks taking too much comfort in security, information asymmetry leading to to moral hazard, economic environment and political influence (Chikoko et al., 2012; Hapsari, 2012). Macroeconomically, the main cause of the high level of NPLs is the economic slowdown, which can be seen from the statistically significant and large economic coefficients on GDP, unemployment and inflation rates (Nurunnabi, 2017).

Capital Adequacy Ratio (CAR) is a ratio that shows how far all bank assets that contain risks (credit, investments, securities, claims on other banks) are also financed from the bank's own capital funds in addition to obtaining funds from sources outside banks, such as funds from the public, loans and others (Mili et al., 2017; Wang et al., 2022). The decrease in CAR is the result of a decrease in the amount of capital of an institution or an increase in the number of risk-weighted assets (RWA). CAR has a negative effect on 
NPL (Apriyantari \& Ramantha, 2018; Setiawan et al., 2019). The Loan to Deposit Ratio is a ratio to measure the composition of the amount of credit given compared to the amount of public funds and own capital used (Bod'a \& Zimková, 2021; Dia \& VanHoose, 2019). Credit distribution is the main activity of banks, therefore the main source of bank income comes from credit. The greater the credit disbursed compared to public deposits in a bank, the consequence is that the greater the risk that must be borne by the bank concerned. KAP is an assessment of asset quality factors based on the comparison of classified earning assets (APYD) to their earning assets The increase in the KAP ratio is influenced by an increase in APYD or a decrease in total productive costs (Capasso \& Neanidis, 2019; Suomi et al., 2020). If the APYD increases, it means that credit is in special attention, substandard credit, doubtful credit, and bad loans also increase. Thus, if the $\mathrm{KAP}$ ratio is high, it means that the level of bad or non-performing loans is also high.

BOPO is the ratio of the ratio between Operating Costs and Operating Income. The BOPO ratio is referred to as the efficiency ratio used to measure the ability of bank management to control operational costs against operating income in their operational activities (Dadang Agus Suryanto \& Susanti, 2020; Rezeki \& Noviarita, 2021). The smaller the BOPO ratio means the more efficient the operational costs incurred by the bank so that the possibility of the bank being in a problematic condition is getting smaller (Alteza, 2017; Harsono, 2021; Pusva \& Herlina, 2017). As a financial institution, the Penglatan Traditional Village LPD is located in Penglatan Village, which is one of the many financial institutions engaged in the savings and loan sector. The Penglatan Traditional Village LPD has activities, namely collecting funds from the community and channeling them back to customers in the form of loans. In providing LPD loans, there is a high level of risk, because any credit given can be problematic. The Penglatan Traditional Village LPD which has many competitors must always pay attention to the existing NPL for the survival of the LPD in the future. The development of loans from 2018 to 2020 owned by the Penglatan Traditional Village LPD. The number of loans realized decreased in 2019 by $13.40 \%$, and in 2020 it increased by $40.26 \%$. Current loans continued to decline from 2018 to 2020 . Substandard loans decreased in 2019 by $74.15 \%$ and increased in 2020 by $1.421 \%$. Doubtful loans decreased in 2019 by $78.34 \%$ and increased in 2020 by $63.80 \%$. And for non-performing loans, the largest increase occurred in 2019 by $9.95 \%$ and in 2020 it decreased by $0.08 \%$, from 2017 to 2020 the non-performing loans in the Penglatan Traditional Village LPD exceeded the maximum limit of $5 \%$. This study aims to analyze the effectiveness of the management of NonPerforming Loan (NPL) in the Penglatan Traditional Village LPD through the Non-Performing Loan (NPL) ratio, Capital Adequacy Ratio (CAR), Loan to Deposit Ratio (LDR), Earning Asset Quality (KAP) and Cost.

\section{METHODS}

This research was conducted at the Village Credit Institution (LPD) Penglatan Traditional Village having its address at Desa, Penglatan Village, Buleleng District, Buleleng Regency. The instrument used to collect data is a questionnaire. This study used a population and sample of 36 months or 3 years using purpostve sampling technique, the collection technique used an observation process on the financial report data obtained at the Penglatan Traditional Village LPD for the 2018-2020 period which calculated the ratio of each variable and used Multiple Linear Regression Analysis, Classical Assumption Test Analysis, F-Test Analysis (F-Test) Determination Analysis and T Test Analysis (T) -Test).

\section{RESULTS AND DISCUSSIONS}

\section{Results}

A ratio is a number that is compared to another number as a relationship. The ratio calculation is used to describe the information regarding the financial position and the effectiveness of the company's performance. In this study, the ratios calculated are the NPL ratio with a standard maximum ratio value of $5 \%$, the CAR ratio with a minimum standard ratio value of $12 \%$, the LDR ratio with a standard maximum ratio value of $94.75 \%$, the KAP ratio with a standard maximum ratio value of $7.80 \%$, , and the BOPO ratio with a standard maximum ratio value of $79.75 \%$. The results of the calculation of the ratio can be seen that the NPL ratio for three years from 2018 to 2020 exceeds the maximum standard limit for the NPL ratio value, in other words, the management of NPL in the Penglatan Traditional Village LPD is still not effective. Furthermore, the results of the calculation of the CAR ratio appear to have exceeded the standard value of the CAR ratio value, which means that CAR management in the Penglatan Traditional Village LPD is quite effective. The results of the LDR and BOPO ratios do not exceed the standard ratio values set, which means that the LDR and BOPO management in the Penglatan Traditional Village LPD is already effective. And for the KAP ratio, it can be seen that the results exceed the maximum standard limit of the KAP ratio, this means that the KAP management in the Penglatan Traditional Village LPD is still not effective. 
The results of the calculation of regression analysis with the SPSS program are related to the variables studied, namely the Effectiveness of NPL Management (Non Performing Loans) at the Village Credit Institution (LPD) of Penglatan Traditional Village as follows:

$\mathrm{Y}=\mathrm{a}+\mathrm{B}_{1} \mathrm{X}_{1}+\mathrm{B}_{2} \mathrm{X}_{2}+\mathrm{B}_{3} \mathrm{X}_{3}+\mathrm{B}_{4} \mathrm{X}_{4}+\mathrm{e}$

$Y=78,020-1,573 X_{1}+0,504 X_{2}+1,739 X_{3}+0,168 X_{4}+11,93$

The results of the normality test using the One-Sample Kolmogorov-Smirnov Test showed that the Asymp Sig. (2-Tailed) has a value of $0.241>0.05$ so it can be concluded that the data used is normally distributed.

Table 1. Multicollinearity Test

\begin{tabular}{lcc}
\hline \multicolumn{1}{c}{ Variable } & \multicolumn{2}{c}{ Collinearity Statistics } \\
\cline { 2 - 3 } & Tolerance & VIF \\
\hline Capital Adequacy Ratio & 0,259 & 3,859 \\
Loan to Deposit Ratio & 0,218 & 4,578 \\
Earning Asset Quality & 0,243 & 4,107 \\
Operating Costs Against Operating Income & 0,610 & 1,640 \\
\hline
\end{tabular}

The tolerance value for each variable is more than 0.1 and the VIP value is less than 10 . Thus, it can be concluded that all independent variables do not experience cases of multicollinearity. Durbin-Watson value $=1.835$, Durbin-Watson table value $(\mathrm{dU})=1.654$, and 4 - $\mathrm{dU}$ value $=2.346$. From these results, it can be seen that the Durbin-Watson value is in the interval $\mathrm{dU}<\mathrm{d}<4$-Du. Because this value is in the interval $\mathrm{dU}<\mathrm{d}<4-\mathrm{dU}$, it can be concluded that the research data obtained have no positive or negative autocorrelation.

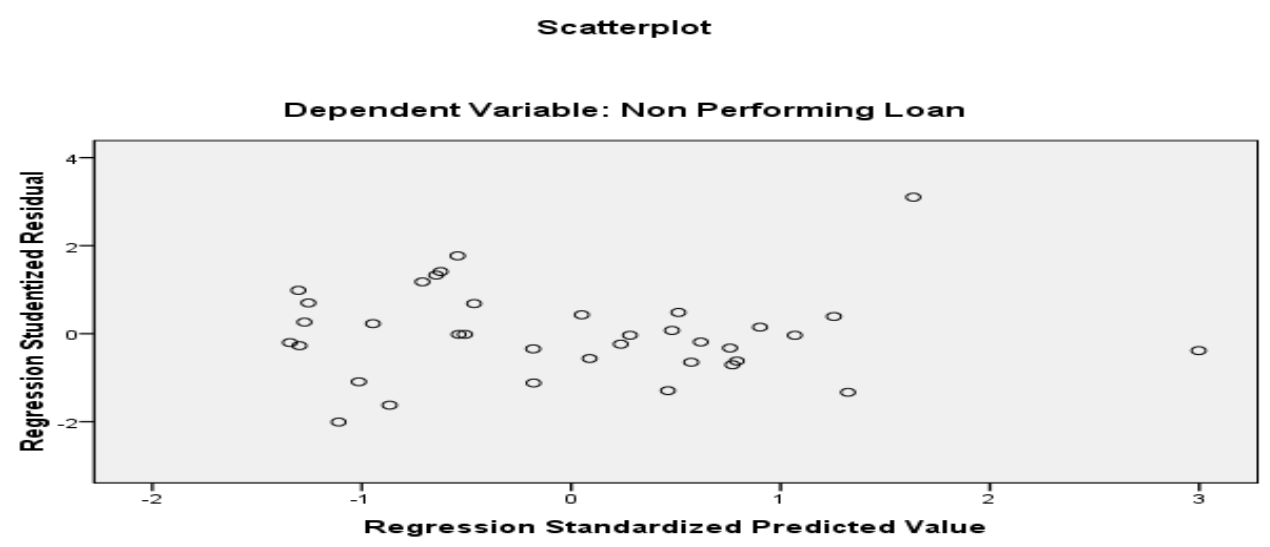

Figure 1. Scatterplot Graph

The results of the scatterplot graph presented in Figure 1 can be seen that the spread of points is spread evenly below and above zero. So it can be said that in the regression model there is no heteroscedasticity problem. The results of the calculation of F-count > F-table, with an F-count value of 102.161 and a significant level of 0.00, this indicates that Operating Costs to Operating Income, Capital Adequacy Ratio, Productive Asset Quality, Loan to Deposit Ratio have an effect on Non-Performing Loans. The correlation coefficient value of R2 (R Square) is 0.929 or (92.9\%). This shows that the percentage of the independent variable's contribution to the dependent variable is $92.9 \%$. Or the variation of the independent variable used in explaining $92.9 \%$ of the variation in the dependent variable. While the remaining $7.1 \%$ is influenced or explained by other variables that are not included in this research model.

CAR (X1) on NPL (Y) has a negative effect, it can be seen from the partial test ( $\mathrm{t}$-test) $=0.000$ smaller than 0.05 . This resulted in the rejection of the accepted $\mathrm{H} 0$ and $\mathrm{H} 1$. The variable regression coefficient (X1) is -1.573; it means that the coefficient is negative, meaning that there is a negative relationship between the Capital Adequacy Ratio and the Non-Performing Loan. (The hypothesis is accepted). LDR (X2) has a positive and significant effect on NPL (Y) The significance value for the variable Loan to Deposit Ratio (X2) $=0.000$ is smaller than 0.05. The regression coefficient for the Loan to Deposit Ratio (X2) variable is 0.504, meaning that the coefficient is positive, meaning that there is a positive relationship between the Loan to Deposit Ratio and the Non-Performing Loan, the better the Loan to Deposit Ratio, the better the Non-Performing 
Loan. (The hypothesis is accepted). KAP (X3) has a positive and significant effect on NPL (Y), with a significance value for the Earning Asset Quality variable $(\mathrm{X} 3)=0.000$ which is smaller than 0.05 . The regression coefficient of the Productive Asset Quality (X3) variable is 1.739; meaning that the coefficient is positive, meaning that there is a positive relationship between the Quality of Earning Assets and NonPerforming Loans, the better the Quality of Earning Assets, the better the Non-Performing Loans. (Hypothesis accepted). BOPO (X4) has a positive and significant effect on NPL (Y) with a significance value for the variable Operating Costs to Operating Income (X4) $=0.036$ which is smaller than 0.05 and the regression coefficient of the Variable Operating Costs to Operating Income (X4) is 0.168; meaning that the coefficient is positive, meaning that there is a positive relationship between Operational Costs on Operating Income and Non-Performing Loans, the better Operating Costs on Operating Income, the better NonPerforming Loans will be. (Hypothesis accepted).

\section{Discussion}

The results above can be explained that the CAR (X1) on NPL (Y) has a negative effect, it can be seen from the partial test ( $\mathrm{t}$-test) $=0.000$ smaller than 0.05 . This resulted in the rejection of the accepted $\mathrm{H} 0$ and $\mathrm{H} 1$. The variable regression coefficient (X1) is -1.573 ; This means that if the other independent variables have a fixed value and the Capital Adequacy Ratio variable has increased by 1 unit, then Non-Performing Loans have decreased by -1.573. A negative coefficient means that there is a negative relationship between the Capital Adequacy Ratio and Non-Performing Loans. (The hypothesis is accepted). The capital has a negative effect on problematic conditions. The CAR has a negative effect on NPL (Kennedy \& Hayrani, 2018; Mili et al., 2017). This gives a negative indication of the effect of CAR on NPL.

The results of this study indicate that LDR (X2) has a positive and significant effect on NPL (Y). The significance value for the variable Loan to Deposit Ratio (X2) $=0.000$ is smaller than 0.05 . The regression coefficient of the Loan to Deposit Ratio (X2) variable is 0.504; This means that if the other independent variables have a fixed value and the Loan to Deposit Ratio has increased by 1 unit, then the Non-Performing Loan will increase by 0.504 . The coefficient is positive, meaning that there is a positive relationship between the Loan to Deposit Ratio and the Non-Performing Loan, the better the Loan to Deposit Ratio, the better the Non-Performing Loan. (The hypothesis is accepted). The number of third party funds collected by a bank is directly proportional to the amount of credit issued, meaning that the more third party funds, the more credit issued (Balke et al., 2021; Bawa \& Basu, 2020; Hernández et al., 2015). The higher the LDR, the lower the liquidity capacity of the bank concerned. This is supported by research conducted that there is a positive influence between LDR and NPL (Bolognesi et al., 2020; Karadima \& Louri, 2020; Tölö \& Virén, 2021).

The results of this study indicate that KAP (X3) has a positive and significant effect on NPL (Y), with a significance value for the Productive Asset Quality variable $(X 3)=0.000$ which is smaller than 0.05 . The regression coefficient of the Productive Asset Quality (X3) variable is 1.739; This means that if the other independent variables have a fixed value and the Quality of Earning Assets has increased by 1 unit, then the Non-Performing Loan will increase by 1.739. The coefficient is positive, meaning that there is a positive relationship between the Quality of Earning Assets and Non-Performing Loans, the better the Quality of Earning Assets, the better the Non-Performing Loans. (Hypothesis accepted). The number of third party funds collected by a bank is directly proportional to the amount of credit issued, meaning that the more third party funds, the more credit issued (Dwiantara et al., 2015; Hernández et al., 2015; Sari et al., 2020). So it can be concluded that if the LDR ratio increases, the liquidity capacity will decrease. This is because the amount of funds needed to finance credit is getting bigger. This is supported by the results of research that there is a positive influence between LDR and NPL (Bod'a \& Zimková, 2021; Sujana \& Mustanda, 2015).

The results of this study can show that BOPO (X4) has a positive and significant effect on NPL (Y) with a significance value for the variable operating costs on operating income $(X 4)=0.036$ which is smaller than 0.05 and the regression coefficient of the variable operating costs on operating income ( X4) of 0.168; This means that if the other independent variables are fixed in value and Operational Costs to Operating Income have increased by 1 unit, then Non-Performing Loans will increase by 0.168 . The coefficient is positive, meaning that there is a positive relationship between Operational Costs on Operating Income and Non-Performing Loans, the better Operating Costs on Operating Income, the better Non-Performing Loans will be. (Hypothesis accepted). The smaller the BOPO ratio means the more efficient the operational costs incurred by the bank concerned so that the possibility of a bank in troubled conditions is getting smaller (Dadang Agus Suryanto \& Susanti, 2020; Rezeki \& Noviarita, 2021). This is supported by the research stated that BOPO had a positive effect on NPL (Alteza, 2017; Harsono, 2021; Pusva \& Herlina, 2017). 


\section{CONCLUSION}

The Capital Adequacy Ratio (CAR) variable has a significant negative effect on NPL in the Penglatan Traditional Village LPD. This shows that when the Capital Adequacy Ratio increases, the Non-Performing Loan will decrease, then secondly, the Loan to Deposit Ratio (LDR) variable has a significant positive effect on NPL in the Penglatan Traditional Village LPD. The quality of Earning Assets (KAP) has a significant positive effect on the NPL in the Penglatan Traditional Village LPD. This shows that the better the Productive Asset Quality, the better the Non-Performing Loans, and finally, the Operational Cost of Operating Income (BOPO) has a significant positive effect on the NPL in the Penglatan Traditional Village LPD.

\section{REFERENCES}

Adiputra, I. M. P., \& Sujana, E. (2021). Management Control Systems, Organizational Culture and Village Credit Institution Financial Performance. The Indonesian Journal of Accounting Research, 24(1). https://doi.org/10.33312/ijar.515.

Alteza, M. (2017). Analisis Determinan Profit Distribution Management Bank Umum Syariah Periode 20132016. Lifalah, 2(2). https://doi.org/10.31332/lifalah.v2i2.653.

Andreana, M. O. C., \& Wirajaya, I. G. A. (2018). Pengaruh Transparancy, Accountability, Responsibility, Independency, dan Fairness Pada Kinerja Keuangan Lembaga Perkreditan Desa. E-Jurnal Akuntansi, 23(2). https://doi.org/10.24843/EJA.2018.v23.i02.p19.

Apriyantari, N. K. D., \& Ramantha, I. W. (2018). Pengaruh Aktiva Produktif, Kecukupan Modal, dan LDR Terhadap Kinerja Keuangan Dengan NPL Sebagai Variabel Moderasi. E-Jurnal Akuntansi, 1(1). https://doi.org/10.24843/EJA.2018.v23.i03.p16.

Balke, N. S., Zeng, Z., \& Zhang, R. (2021). Identifying credit demand, financial intermediation, and supply of funds shocks: A structural VAR approach. The North American Journal of Economics and Finance, 56. https://doi.org/10.1016/j.najef.2021.101375.

Bawa, J. K., \& Basu, S. (2020). Restructuring assets reform, 2013: Impact of operational ability, liquidity, bank capital, profitability and capital on bank credit risk. IIMB Management Review, 32(3). https://doi.org/10.1016/j.iimb.2019.10.009.

Bod'a, M., \& Zimková, E. (2021). Overcoming the loan-to-deposit ratio by a financial intermediation measure - A perspective instrument of financial stability policy. Journal of Policy Modeling, 43(5). https://doi.org/10.1016/j.jpolmod.2021.03.012.

Bolognesi, E., Compagno, C., Miani, S., \& Tasca, R. (2020). Non-performing loans and the cost of deleveraging: The Italian experience. Journal of Accounting and Public Policy, 39(6). https://doi.org/10.1016/j.jaccpubpol.2020.106786.

Capasso, S., \& Neanidis, K. C. (2019). Domestic or foreign currency? Remittances and the composition of deposits and loans. Journal of Economic Behavior \& Organization, 160. https://doi.org/10.1016/j.jebo.2019.01.023.

Chikoko, L., Mutambanadzo, T., \& Vhimisai, T. (2012). Insights on Non-Performing Loans: Evidence from Zimbabwean Commercial Banks in a Dollarised Environment (2009-2012). Journal of Emerging Trends in Economics and Management Sciences, 3(6).

Dadang Agus Suryanto, \& Susanti, S. (2020). Analisis Net Operating Margin (NOM), Non Performing Financing (NPF), Financing to Debt Ratio (FDR) dan Pengaruhnya Pada Efisiensi Perbankan Syariah di Indonesia. Jurnal Riset Akuntansi Dan Keuangan, 8(1). https://doi.org/10.17509/jrak.v8i1.19331.

Damayanthi, E. (2011). Pengungkapan Tanggung Jawab Sosial Lembaga Perkreditan Desa (Lpd) Berdasarkan Filosofi Tri Hita Karana. Jurnal Ilmiah Akuntansi Dan Bisnis, 6(2).

Dia, E., \& VanHoose, D. (2019). Real resource utilization in banking, economies of scope, and the relationship between retail loans and deposits. Economics Letters, 177. https://doi.org/10.1016/j.econlet.2019.01.018.

Dwiantara, I. K. P., Darmawan, N. K. S., \& Atmadja, I. B. P. (2015). Penanggulangan Kredit Macet Melalui Proses Restrukturisasi Pada Bank Rakyat Indonesia Cabang Negara, Kabupaten Jembrana. Kertha Semaya, 3(3).

Gazzola, P., Pavione, E., Pezzetti, R., \& Grechi, D. (2020). Trends in the fashion industry. The perception of sustainability and circular economy: A gender/generation quantitative approach. Sustainability (Switzerland), 12(7), 1-19. https://doi.org/10.3390/su12072809.

Hapsari, E. (2012). Kekuatan Rasio Keuangan dalam memprediksi kinerja keuangan. Jurnal Dinamika Manajemen, 3(2). https://doi.org/10.15294/jdm.v3i2.2438.

Harsono, K. (2021). Analisis Faktor-faktor Profitabilitas Bank. Jurnal Maksipreneur: Manajemen, Koperasi, Dan Entrepreneurship, 10(10). https://doi.org/10.30588/jmp.v10i2.774. 
Hernández, S. M., Gil, E. G., \& Renart, M. A. (2015). Spanish credit institutions: do efficiency and solvency support the first decisions on bank restructuring from a financial point of view 2008-2012? Contaduría y Administració, 60(2). https://doi.org/10.1016/S0186-1042(15)30005-X.

Hyman, M., Mark, C., Imteaj, A., Ghiaie, H., Rezapour, S., Sadri, A. M., \& Amini, M. H. (2021). Data analytics to evaluate the impact of infectious disease on economy: Case study of COVID-19 pandemic. Patterns, 2(8), 100315. https://doi.org/10.1016/j.patter.2021.100315.

Ibn-Mohammed, T., Mustapha, K. B., Godsell, J., Adamu, Z., \& Babatunde, K. A. (2021). A critical analysis of the impacts of COVID-19 on the global economy and ecosystems and opportunities for circular economy strategies. Resources, Conservation and Recycling, 164. https://doi.org/10.1016/j.resconrec.2020.105169.

Jayanthi, Suhariningsih, \& Safa'at R., H. S. (2021). The Concept Of Sekala Niskala In Credit Agreements At Labda Pacingkreman Desa Bali Traditional Village. Russian Journal of Agricultural and SocioEconomic Sciences, 115(7). https://doi.org/10.18551/rjoas.2021-07.03.

Karadima, M., \& Louri, H. (2020). Non-performing loans in the euro area: Does bank market power matter? International Review of Financial Analysis, 72. https://doi.org/10.1016/j.irfa.2020.101593.

Kennedy, P. S. J., \& Hayrani, R. (2018). Pengaruh Faktor-faktor Ekonomi Makro: Inflasi, Harga Minyak, dan Harga Bahan Bangunan Terhadap Harga Saham Perusahaan Properti di BEI. Jurnal Mitra Manajemen, 2(1), 1-12.

Konstantakis, K. N., Michaelides, P. G., \& Vouldis, A. T. (2016). Non performing loans (NPLs) in a crisis economy: Long-run equilibrium analysis with a real time VEC model for Greece (2001-2015). Physica A: Statistical Mechanics and Its Applications, 456. https://doi.org/10.1016/j.physa.2015.12.163.

Mahaendrayasa, P. K. A., \& Putri, G. A. M. A. D. (2017). Pengaruh Prinsip-Prinsip Good Corporate Governance Terhadap Kinerja Keuangan Lembaga Perkreditan Desa (LPD) di Kota Denpasar. E-Jurnal Akuntansi, 21(2). https://doi.org/10.24843/EJA.2017.v21.i02.p04.

Malik, P. K., Singh, R., Gehlot, A., Akram, S. V., \& Das, P. K. (2022). Village 4.0: Digitalization of village with smart internet of things technologies. Computers \& Industrial Engineering, 165. https: //doi.org/10.1016/j.cie.2022.107938.

Mili, M., Sahut, J.-M., Trimeche, H., \& Teulon, F. (2017). Determinants of the capital adequacy ratio of foreign banks' subsidiaries: The role of interbank market and regulation. Research in International Business and Finance, 42. https://doi.org/10.1016/j.ribaf.2016.02.002.

Nurunnabi, M. (2017). The myth of tax evasion in south Asia: The case of a lower-middle income economy. Advances in Public Interest Accounting, 20, 85-133. https://doi.org/10.1108/S1041706020170000020005.

Prena, G. Das, \& Kustina, K. T. (2017). Kegiatan Sosial, Budaya, Dan Agama Dalam Menentukan Laba Lembaga Perkreditan Desa (Lpd) Kota Denpasar. E-Jurnal Akuntansi, 21(1).

Pusva, I. D., \& Herlina, E. (2017). Analysis of the implementation of green banking in achieving operational cost efficiency in the banking industry. Indonesian Accounting Review, $7(2)$. https: //doi.org/10.14414/tiar.v7i2.1602.

Rezeki, I. H., \& Noviarita, H. (2021). Analisis Rasio Kinerja Keuangan Bank Muamalat Indonesia Pada Masa Pandemi Covid-19. Islamic Economics Journal, 7(1). https://doi.org/10.21111/iej.v7i1.6498.

Saerang, I., Tommy, P., \& Christiano, M. (2014). Analisis Terhadap Rasio-rasio Keuangan Untuk Mengukur Profitabilitas Pada Bank-bank Swasta Yang Go Public Di Bursa Efek Indonesia. Jurnal Riset Ekonomi, Manajemen, Bisnis Dan Akuntansi, 2(4), 817-830. https://doi.org/10.35794/emba.v2i4.6490.

Sanjaya, N. M. W. S., Nopiyani, P. E., \& Rianita, N. M. (2019). Kualitas Laporan Keuangan Ditinjau dari Budaya Tri Hita Karana, GCG, Kompetensi SDM dan Manajemen Risiko Lembaga Perkreditan Desa. Jurnal Riset Akuntansi Dan Keuangan, 7(3). https://doi.org/10.17509/jrak.v7i3.17628.

Sari, L. M., Musfiroh, L., \& Ambarwati, A. (2020). Restrukturisasi Kredit Bank Daerah X Pada Masa Pademi Covid-19. Jurnal Manajemen Dan Akutansi, 8(1).

Setiawan, R., Putri, N. R., \& Rachmansyah, A. B. (2019). Determinant Net Interest Margin Pada Bank Perkreditan Rakyat Indonesia. Jurnal Riset Dan Bisnis, 12(2). https://doi.org/10.23969/jrbm.v12i2.1666.

Skarica, B. (2014). Determinants of Non-Performing Loans in Central and Eastern European countries. Financial Theory and Practice, 38(1). https://doi.org/10.3326/fintp.38.1.2.

Suarta, I. M., \& Sudiadnyani, I. O. (2014). Studi Faktor Penentu Penerimaan Dan Penggunaan Sistem Informasi Akuntansi Pada Lembaga Perkreditan Desa. Jurnal Sistem Informasi Uournal of Information System), 10(1). https://doi.org/10.21609/jsi.v10i1.377.

Sujana, P. C., \& Mustanda, I. K. (2015). Pengaruh Cash Turnover, Loan to Deposit Ratio, Capit al Adequacy Ratio, dan Dana Pihak Ketiga terhadap Profitabilitas LPD. Jurnal Manajemen, Strategi Bisnis Dan 
Kewirausahaan, $8(2)$.

Suomi, V., Järvinen, J., Kiviniemi, T., Ylitalo, A., \& Pietilä, M. (2020). Full feature selection for estimating KAP radiation dose in coronary angiographies and percutaneous coronary interventions. Computers in Biology and Medicine, 120. https://doi.org/0.1016/j.compbiomed.2020.103725.

Suputra, I. D. G. D., \& Hendrayanti, N. L. P. (2021). Pengaruh Prinsip-Prinsip Good Corporate Governance pada Kinerja Keuangan Lembaga Perkreditan Desa. E-Jurnal Akuntansi, 30(1). https://doi.org/10.24843/EJA.2020.v30.i09.p09.

Suwintana, I. K., Sudhana, I. G. P. F. P., \& Hariyanti, N. K. D. (2018). Pengembangan Aplikasi Mobile Teller Lembaga Perkreditan Desa Berbasis Android. Matrix: Jurnal Manajemen Teknologi Dan Informatika, 83(10). https://doi.org/10.31940/matrix.v8i3.823.

Tölö, E., \& Virén, M. (2021). How much do non-performing loans hinder loan growth in Europe? European Economic Review, 136. https://doi.org/10.1016/j.euroecorev.2021.103773.

Tomar, S., \& Sharma, N. (2021). A systematic review of agricultural policies in terms of drivers, enablers, and bottlenecks: Comparison of three Indian states and a model bio-energy village located in different agro climatic regions. Groundwater for Sustainable Development, 15. https://doi.org/10.1016/j.gsd.2021.100683.

Wang, J., Chen, H., Zhang, H., Luo, J., Cheng, M., \& Zhang, J. (2022). Property rights reform and capital adequacy ratios of rural credit cooperatives in China. Economic Modelling, 106. https://doi.org/10.1016/j.econmod.2021.105707.

Wilatini, K. A. D., \& Wirakusuma, M. G. (2019). Pengaruh Pengendalian Internal Pada Efisiensi Kredit Di Lembaga Perkreditan Desa (LPD) Se-Kecamatan Sukawati Kabupaten Gianyar. E-Jurnal Akuntansi, 28(2). https://doi.org/10.24843/EJA.2019.v28.i02.p04. 